\title{
GENERAL THEORY OF LINGUISTIC VARIATION
}

\author{
Sultanova Sevara ${ }^{1}$ \\ ${ }^{1}$ Lecturer at the Department of Russian Language, Ferghana State University, Ferghana, \\ Uzbekistan
}

\author{
Alimov Timur ${ }^{2}$ \\ ${ }^{2}$ Lecturer at the Department of Methodology of Russian Language, Ferghana State \\ University, Ferghana, Uzbekistan
}

Article DOI: https://doi.org/10.36713/epra6058

\begin{abstract}
At this stage in the development of linguistics, a special place is occupied by the theory of variability, which for a long time has attracted the close attention of linguists. In order to understand the principles of development of diachrony and synchronicity of the functioning of the language, it is necessary to understand the deep and comprehensive study of variance. In the last decade, the subject of interest of most linguists is the problem of variance and variability, and in theoretical terms it has not yet been studied.
\end{abstract}

KEY WORDS AND EXPRESSIONS: variance, variability, variant / invariant, language functioning, linguistic units, synchronicity and diachrony.

\section{INTRODUCTION}

The aim of this study is the theory of variability and its functioning in the modern Russian language. At each stage of the existence of a language, there are elements in it that are generated and die off, the diversity of which leads to the appearance of variance of linguistic units. Thus, variance serves for synchrony and diachrony and maintains continuity in the development of the language system.

At the present stage of the development of linguistics, variance occupies a special place, since one of the most important problems of linguistic variance remains. According to K. Aymermacher, "Variations are characteristic of any level of language at any stage of its development. It can be proved that it is variation that acts as a form of connection between synchrony and diachrony, since the unity of synchrony and diachrony manifests itself at any given moment in the variability of linguistic elements" [1, p. 4]. A.D. Travkina argues that the term "variation" should be used to denote the phenomenon or concept itself, and "variability" - to the results of the action of this process [4, p. 78].

\section{DISSCUSION}

A number of scholars (O. B. Sirotinina, N.N. Semenyuk, F.P. Filin) consider variability from the standpoint of formal variation, variation of the plan of expression with the identity (proximity) of the content plan. Linguists distinguish broad and narrow interpretations of variance [3, p. 63-64]. In their understanding, variability in a broad sense represents inconsistency in meaning and modification. Opposing a variant to an invariant does not find its necessity at this stage. Synchrony in the narrow sense of variability is a characteristic of the way of existence and functioning of language units. A dichotomy is characterized by the quality of abstraction abstracted from a specific linguistic unit.

Likewise, the phenomenon of linguistic variance (variation) is defined in science as "a 


\section{EPRA International Journal of Research and Development (IJRD)}

difference in reproduction, consisting in changing the sound composition or meaning of a structural unit of language without losing its identity" [1, p. 72]. Based on the foregoing, linguistic variance reveals a certain modification that does not lead to the emergence of something new, but, according to V.M. Solntseva, "assumes both variability and constancy, acting as a unity of changeable and constant" [2, p. 32]. Linguistic variants are "different manifestations of the same essence, for example, a modification of the same unit, which remains by itself with all changes" $[2$, p. 32]. in the language system they belong to one of certain tiers. In recent years, variant units have been described in the aspect of intercultural communication. - phonetic, morphological, syntactic, lexical, which to a large extent determines the total composition of variant units as means of expression, similarly compared with the designated.

Variation (variance) is one of the most general concepts in linguistics, thereby providing an opportunity to study it both in terms of studying the language system, and in terms of using specific variant units. In this regard, N.M. Solntsev states: "In linguistics, the concept of variability (variance) is used in two ways. First, as a characteristic of any linguistic variability, modification that may be the result of evolution, the use of different means of language to denote similar or the same phenomena, or the result of other reasons. With this understanding, there is no need for the division of variance-invariance. Secondly, the concept of variability is used as a characteristic of the way of existence and functioning of language units in synchrony, acting against the background of the concept of invariance " [2, p. 32].

The difference between the two terms has led to the fact that at this stage of the development of linguistics there is an opinion about the need to distinguish between the terms "variability" and "variance". So, in our opinion, these terms are used differentially: to the first term, the variation of the language system, denoted by the term "variability", and to the second meaning, the variation of language units, denoted by the term "variance". Thus, variance, as opposed to variability, can be viewed as a rapidly developing dynamics and process of language change, and variance as a result of these rapidly developing dynamic changes that manifest themselves in the language system itself and find their place in the existence of variants. This approach is considered to be completely proven, since the very existence of two understandings of variability allows its two-fold terminological labeling.

During the functioning of the language and the transition from language to speech, the problem of variance arises, as well as, if necessary, explain the different meanings of the same variant units in linguistics. In this regard, the above may not use all the cases when there is a need for attention to the term variability, but is considered the most relevant and frequently used.

When we study literary texts, as well as colloquial speech, it gives us reason to believe that variance is considered in all aspects of linguistics. So, for example, we consider variance from the point of view of a literary text in a phrase, expressing attributive meanings, which contain a wide variability if they find their state in various adjacent forms. These meanings are constantly used by different means, distributed between different verbs, but they can be carried out with the same verb. Variation can come in three forms from the point of view of formal organization. In the first case, variable relationships can enter into an unlimited, reliable form and form with an excuse (work a month - for a month, read at night - at night, repeat the fifth time for the fifth time, achieve something by persistence thanks to persistence), and in the second in the case of reliable forms with pretexts (to sit at the table - at the table, to be silent at lunch - during lunch - during lunch, walk from a kilometer - about a kilometer) and in the third case, a reliable form and infinitive (come to dinner - by lunchtime - for lunch, rush to help help, get tired of waiting - from waiting). In the information field of the younger generation, variance is manifested in the need to shorten words due to rapidly changing means of communication, for example: (advertisement - ad, comfortable - comfy, promotion - promo, substitute - sub, underwear undies).

\section{CONCLUSION}

In conclusion, variability and variance are continuously evolving phenomena and require constant attention from linguists to maintain and develop the freshness of the language. Thus, variance is a continuous process of dynamic changes in the language, reflected in the language system and manifested in the presence of certain variants of the language, and the concept of variability usually shows the presence of the ability to change the type of units, and linguistic expression is most fully manifested in linguistic activity and thus we we can say that variance is already fixed in the language, while variability has a potential driving force that constantly lives and causes certain linguistic changes.

The emergence of variability, therefore, is due to several factors of human thinking, and one of them, of course, is due to the fact that the younger generation strives to reduce complex words by replacing the simplest units in communication, both in writing and in colloquial speech. 
SJIF Impact Factor: 7.001| ISI I.F.Value:1.241| Journal DOI: 10.36713/epra2016 ISSN: 2455-7838(Online)

EPRA International Journal of Research and Development (IJRD)

Volume: 6 | Issue: 1 | January 2021

- Peer Reviewed Journal

\section{REFERENCES}

1. Аймермахер К. Знак. Текст. Культура// Пер. с нем. С.А.Ромашко. - М.: Дом интеллектуальной книги, 1998. 4- 260 с.

2. Солнщев B.M. Языковой знак и его свойства// Вопросы языкознания. - 1977. - № 2.

3. Сиротинина О.Б. Межстилевая и внутристилевая вариантность языковой системь // Вариантность как свойство языковой системы. М., 1982. Ч. 2. С. 63-64.

4. Травкина А.Д. Динамика фонетической формы английского слова. Калинин, 1988. 